\title{
Magdalena Szymczak
}

University of Economics in Katowice

e-mail:magdalena.szymczak@ue.katowice.pl

ORCID: 0000-0001-8262-6207

\section{GOOD PRACTICE FOR TRANSFER PRICING IN SELECTED OECD COUNTRIES}

\author{
DOI: $10.15611 /$ pn.2020.9.09 \\ JEL Classification: F23, H87, K34
}

\section{(C) 2020 Magdalena Szymczak}

This work is licensed under the Creative Commons Attribution-ShareAlike 4.0 International License. To view a copy of this license, visit http://creativecommons.org/licenses/by-sa/4.0/

Quote as: Szymczak, M. (2020). Good practice for transfer pricing in selected OECD countries. Prace Naukowe Uniwersytetu Ekonomicznego we Wroctawiu, 64(9).

\begin{abstract}
Over the past decades the use of transfer pricing has increased significantly. It was noted that transfer pricing impacts on many areas of enterprise management. Countries, observing the gravity of the issue and taking care of securing their tax base, began to adopt regulations governing this matter. To meet the needs of both enterprises and regulators, international organisations have been working on developing guidelines and promoting them to adopt regulations on transfer pricing that are as clear and transparent as possible. Good practices included in the OECD Guidelines have become the most universally applicable. The paper aims to assess internationally developed solutions regarding transfer pricing based on the example of good practices contained in the OECD Guidelines regarding advance pricing agreements and mutual agreement procedures. The analysis covered all OECD Member States.
\end{abstract}

Keywords: transfer pricing, OECD Guidelines, Advance Pricing Arrangements, Mutual Agreement Procedure.

\section{Introduction}

Transfer pricing has begun to play an increasingly crucial role in boosting the efficiency of entities. Enterprises understood that an interdisciplinary approach to managing transactions between associated companies from different countries can have a positive impact on the operation of the entire enterprise. On the other hand, the abusive transfer pricing of international enterprises (the so-called 'transfer mispricing') led to the erosion of the tax base of countries. Therefore, international 
organisations have taken action to develop guidelines for state tax administrations and international enterprises to use transfer pricing in the international space in a transparent way and to facilitate the harmonisation of the implemented regulations as much as possible. "The OECD Guidelines on Transfer Pricing for Multinational Enterprises and Tax Administrations" are particularly important in this respect.

The aim of the work is to assess solutions developed internationally regarding transfer pricing using the example of advance pricing agreements and mutual agreement procedures, and how Polish solutions compare against this background. Therefore a comparative analysis has been carried out regarding the application of the solutions contained in the OECD Guidelines, and those from all 36 OECD member states were selected for the study.

The results of the comparative analysis made it possible to determine in what legal and economic conditions international enterprises currently operate. As a research hypothesis, it was assumed that the OECD member states largely take into account good practices in the field of advance pricing agreements and mutual agreement procedures. The following research methods were used in the work: analysis of legal acts, analysis of domestic and foreign literature, analysis of reports published by states and international organizations, comparative and tabular analysis, graphical presentation of data.

\section{The essence of transfer pricing}

Transfer pricing policy is an important element of tax optimisation used to maximise the economic efficiency of enterprises. Therefore, the possibility of transferring income within associated enterprises is becoming an increasingly discussed and considered issue (Wiśniewski and Komer, 2015, p. 21).

Transfer prices are derived from bilateral transactions between responsibility centres as part of a single company operation. Problems related to determining the correct value of operations between associated entities were identified in the economic space (Bzymek-Iwanowicz, 2014, p. 27). Tax offices in the US had had the right to make adjustments to the amount of transactions concluded between associated enterprises before the requirement to submit consolidated financial statements was introduced (Miller and Oats, 2014, p. 356).

The United Nations recognises the importance of transfer pricing. In its document, the UN emphasises that from the perspective of finances and their management, taking into account the current economic conditions and the international nature of operations, transfer prices may most likely be indicated as a tax issue of the highest degree of significance (United Nations, 2017, p. 30).

Transfer prices are a multi-faceted phenomenon. Therefore enterprises are required to take an interdisciplinary approach to them. Not only are transfer prices considered in the area of tax or finance, but also their impact on management and management accounting is examined (Zbaraszewska, 2017, pp. 200-201). 
One of the most important definitions of a transfer price is the formulation adopted by the Organisation for Economic Cooperation and Development. It indicates that the transfer price is determined for accounting purposes in order to correctly determine the value of the transaction between associated entities under one management board, the amount of which is abnormally high or low. As a consequence of these actions, there is an unspecified transfer of income from one associated company to another or the movement of capital (OECD, 2002, p. 228).

The Ministry of Finance in Poland, working on legislative projects on transfer pricing, uses the materials developed by the OECD as well as the European Union (Ministry of Finance, 2017). An important definition under Polish tax regulations is the explanation of the transfer price contained in the General Tax Code, the essence of which reflects the assumptions presented in the explanation proposed by the OECD. Pursuant to the General Tax Code, the transfer price is the value of the object of the transaction that was used by associated enterprises (Act of August 29, 1997).

The complexity of the issue, the desire of enterprises to make their profits as high as possible, and the lack of one best calculation option for all transactions under transfer pricing, can lead to both positive and negative effects not only on the scale of enterprises and corporate social responsibility, but also the entire economic interest of the state (Chmiel, 2015, p. 82). The term "transfer mispricing" is being used with an increasing frequency in the subject literature. Transfer mispricing refers to the deliberate, inappropriate setting of the transaction price between related entities, for example by planning the prices of goods between related entities in countries with high and low tax rates mainly in order to minimize the tax burden (Wier, 2020, p. 2).

Some researchers postulate looking at transfer pricing from a broader perspective and take into account corporate social responsibility and ethics in relation to tax aggressiveness and transfer prices. According to their view, practitioners should be involved and transfer prices should be embedded in both the social, political and organisational context to prevent the negative effects that deplete the wealth of countries (Sikka and Willmott, 2010, p. 29). What is more, the research conducted by Lanis, Richardson and Taylor may provide a new perspective in this field. It was found that companies with a higher moral standard less often use aggressive techniques in the context of transfer pricing (Lanis, Richardson, and Taylor, 2019, p. 337).

\section{OECD transfer pricing guidelines}

In addition to the regulations introduced in Poland and the documents issued by the European Union on transfer prices, one can indicate the recommendations and guidelines of international organisations. Documents of this kind are classified as so-called 'soft law.' This means that states countries not forced to apply the provisions contained in these documents. However, states may voluntarily join a group of countries that adhere to the regulations and undertake to apply the recommendations arising from a given document. Although it cannot be said that 
'soft law' ranks the same as 'hard law' when in force, but from the perspective of efficiency with which the obligations are created, the regulations of 'soft law' are not inferior to the regulations classified as 'hard law' in terms of its influence on states (Bańczyk, 2016, pp. 63-64,71). The literature indicates that it is important for enterprises not only to know the national provisions regarded as 'hard law,' but also those applicable in tax planning, and while striving to reduce tax risk, enterprises should be guided by recommendations, good practices or guidelines classified as 'soft law' (Burchart, 2015, p. 48).

An example of a document classified as 'soft law' which is of great importance for tax regulations on transfer pricing around the world are the "OECD Guidelines on Transfer Pricing for Multinational Enterprises and Tax Administrations" (OECD Guidelines). Not only have they become a point of reference in international practice, but also have a strong impact on shaping the internal policies of countries which belong to the OECD (Vega, 2012, p. 15).

Countries may base their national law on the OECD Guidelines to varying degrees and use different methods. The OECD Guidelines impact on national regulations in three basic ways, namely: references directly contained in national legislation, references contained in administrative orders and references in case law (Vega, 2012, pp. 19-27). Countries that base their regulations on OECD good practices, e.g. in terms of the 'arm's length' principle, strive to obtain provisions of the highest possible standard which translates into the development of a practice that is accepted by both tax authorities and multinational enterprises. The mutual acceptance of the method has a positive impact on reducing the number of conflicts between the tax administration and enterprises, misunderstandings as to the proper interpretation between different tax authorities and the number of litigations (OECD, 2017, p. 18).

\section{Good practices as a criterion for assessing transfer pricing solutions}

Countries aim at achieving the highest possible budget revenues by adapting their tax policies. What is more, they focus on generating the greatest possible economic growth. Therefore transfer prices and their impact on the state budget are being subject to an ever deeper analysis. In addition, the effectiveness of the solutions adopted in terms of transfer pricing is assessed as well as the extent to which the regulations affect taxpayers' behaviour, e.g. an important issue is whether the recording requirements are not too detailed and the cost of their compilation is not too high for taxpayers (Przydatek, 2018, pp. 63-64).

In the era of globalisation, it is standard procedure for countries to have regulations on transfer pricing. Hence more and more countries are choosing to use 'good practices' developed in the OECD Guidelines. The application of similar laws and 'good practices' by countries facilitates the expansion of enterprises' activities to new markets and reduces the costs of preparing documentation. 
Transfer pricing regulations on advance pricing agreements and mutual agreement procedures have been gaining importance in recent years. An advance pricing agreement is an agreement between the taxpayer and the tax authority to confirm the accuracy of the transfer pricing method used by the enterprise (Soltysik, 2015, p. 105). The concept of advance pricing agreements is relatively new. The agreement that took place in 1991 between Australia and the United States is considered to be the earliest example of this procedure (Selezen and Hrytsiuk, 2019, p. 481). Depending on how many tax authorities from different countries are involved, the following types of agreements are indicated: unilateral, bilateral and multilateral APAs (Brychta and Sulik-Górecka, 2019, p. 211).

Under the mutual agreement procedure, the tax administrations of the countries competent to associated entities establish such market conditions for the transaction that those transactions are not subject to later challenge by either party. Thanks to this operation, companies that conduct transactions with each other and their headquarters gain the advantage of avoiding the need to pay double tax for the same transaction in other countries of their operation (Rödl \&Partner, 2019), while the tax authorities are sure that the treaty provisions are not breached (Taramountas, 2019, p. 39-40).

The OECD Guidelines recommend bilateral and multilateral agreements in accordance with the principles of the mutual agreement procedure. In such cases, the Ministry of Finance first concludes an agreement with the competent tax authority/ authorities (for the company/companies associated with the domestic entity). Then the domestic entity receives an administrative decision (Ministry of Finance, 2018). Table 1 summarises selected good practices that can be used by countries when developing domestic regulations on advance pricing agreements and mutual agreement procedures.

Table 1. Good practices for countries under the OECD Guidelines for mutual agreement procedure (MAP) and advance pricing agreements (APA)

\begin{tabular}{|c|c|c|}
\hline No. & Good practice & Rationale for selection \\
\hline 1 & 2 & 3 \\
\hline 1. & $\begin{array}{l}\text { "Whenever possible, an APA should be concluded } \\
\text { on bilateral or multilateral basis between competent } \\
\text { authorities through the mutual agreement procedure } \\
\text { of the relevant treaty." (Chapter IV Point } 4.173 \text { ) }\end{array}$ & $\begin{array}{l}\text { - bilateral and multilateral APA } \\
\text { contribute to greater transparency } \\
\text { and reduce the costs associated with } \\
\text { regulatory inquiries or possible } \\
\text { penalties for applying inappropriate } \\
\text { regulations, } \\
\text { - ensuring single taxation, } \\
\text { - bilateral APA may be the only form } \\
\text { of agreement with some states. }\end{array}$ \\
\hline 2. & $\begin{array}{l}\text { "Countries with bilateral APA programmes should } \\
\text { provide for the roll-back of APAs (to previous filed }\end{array}$ & $\begin{array}{l}\text { - beneficial solution in determining } \\
\text { comparable transactions in earlier }\end{array}$ \\
\hline
\end{tabular}


Table 1, cont.

\begin{tabular}{|c|c|c|}
\hline 1 & 2 & 3 \\
\hline & $\begin{array}{l}\text { tax years not included within the original scope of } \\
\text { the APA) in appropriate cases, subject to applicable } \\
\text { time limits (such as domestic law statutes of } \\
\text { limitation for assessments) where the relevant facts } \\
\text { and circumstances in the earlier tax years are the } \\
\text { same and subject to verification of these facts and } \\
\text { circumstances on audit." (Annex II to Chapter IV } \\
\text { Point 69) }\end{array}$ & $\begin{array}{l}\text { years, e.g. when resolving a query } \\
\text { by tax administrations }\end{array}$ \\
\hline 3. & $\begin{array}{l}\text { Countries in their regulations should provide access } \\
\text { to the mutual agreement procedure in transfer } \\
\text { pricing cases. (Chapter IV Point 4.43) }\end{array}$ & $\begin{array}{l}\text { - the solution favours the primary } \\
\text { purpose of tax contracts }\end{array}$ \\
\hline 4b. & $\begin{array}{l}\text { "Countries should identify in their mutual } \\
\text { agreement procedure programme guidance whether } \\
\text { audit settlements between tax authorities and } \\
\text { taxpayers do not preclude access to the mutual } \\
\text { agreement procedure." } \\
\text { "Countries' mutual agreement procedure } \\
\text { programme guidance should include: an } \\
\text { explanation of the relationship between the } \\
\text { mutual agreement procedure and domestic law } \\
\text { administrative and judicial remedies." } \\
\text { Countries' mutual agreement procedure programme } \\
\text { guidance should "provide that taxpayers will be } \\
\text { allowed access to the mutual agreement procedure } \\
\text { so that the competent authorities can resolve } \\
\text { through consultation the double taxation that can } \\
\text { arise in the case of bona fide taxpayer initiated } \\
\text { foreign adjustments." (Chapter IV Point 4.63) }\end{array}$ & $\begin{array}{l}\text { easier access to the guidelines on } \\
\text { the mutual agreement procedure } \\
\text { programme for taxpayers, } \\
\text { greater procedure transparency, } \\
\text { recognition of the taxpayer's bona } \\
\text { fide. }\end{array}$ \\
\hline 5. & $\begin{array}{l}\text { Countries should "identify in that guidance } \\
\text { [regarding the mutual agreement procedure] the } \\
\text { specific information and documentation that } \\
\text { a taxpayer is required to submit with a request for } \\
\text { mutual agreement procedure assistance." (Chapter } \\
\text { IV Point 4.44) }\end{array}$ & \\
\hline
\end{tabular}

Source: own study based on (OECD, 2016, part B point 15; OECD, 2017, Chapter IV points 4.43, 4.44, 4.62., 4.63, 4.173, Annex II to Chapter IV point 69).

The good practices presented in Table 1 from the OECD Guidelines form the basis for developing a model for a comparative analysis of the use of good practices regarding transfer pricing in the OECD member states. 


\section{Comparative analysis of transfer pricing solutions in $O E C D$ countries}

Each guideline presented in Table 1 is a minimum of one criterion used to calculate how many of those guidelines were implemented in each country. It was assumed that each criterion is worth 1 point. If the country does not meet the criterion, then it receives 0 points. In the absence of data or the ambiguous answer, 'yes' or 'no,' the sign '-' will be used and the state will not receive points in this case either.

Table 2 summarises the results of the survey based on national profiles posted on the OECD website. For most countries, data from 2018 and 2019 were adopted. Two countries updated their data and have reports from 2020. For some countries, due to the lack of data, it was necessary to use the available reports from 2016 and 2017.

Table 2. Analysis of the implementation of good practices from the OECD Guidelines on transfer pricing to national solutions

\begin{tabular}{|l|c|c|c|c|c|c|c|c|}
\hline \multicolumn{1}{|c}{ Country/criterion } & 1 & 2 & 3 & $4 \mathrm{a}$ & $4 \mathrm{~b}$ & $4 \mathrm{c}$ & 5 & TOTAL \\
\hline Chile & 1 & 0 & 1 & - & 0 & - & 0 & 2 \\
\hline Iceland & 0 & - & 1 & 1 & 1 & 1 & 0 & 4 \\
\hline Czech Republic & 1 & 0 & 1 & 1 & 0 & 1 & - & 4 \\
\hline Turkey & 1 & 1 & 1 & - & 1 & 1 & 1 & 6 \\
\hline Portugal & 1 & 0 & 1 & 1 & 1 & 1 & 1 & 6 \\
\hline Slovenia & 1 & - & - & - & 1 & 1 & 1 & 4 \\
\hline Italy & 1 & 0 & 1 & 1 & 1 & 0 & 1 & 5 \\
\hline Israel & - & 0 & 1 & 1 & 1 & 1 & 1 & 5 \\
\hline Greece & 1 & 0 & 1 & - & 1 & 1 & 1 & 5 \\
\hline Latvia & 0 & 0 & 1 & 1 & 0 & 1 & 1 & 4 \\
\hline Slovakia & 1 & 1 & 1 & 1 & 0 & 1 & 1 & 6 \\
\hline USA & 1 & 1 & 1 & 1 & 1 & 1 & 1 & 7 \\
\hline Estonia & 1 & 1 & 1 & 1 & 1 & 1 & 1 & 7 \\
\hline Ireland & 1 & 1 & 1 & 1 & 1 & 1 & 1 & 7 \\
\hline Luxembourg & - & - & 1 & - & 1 & 1 & 1 & 4 \\
\hline Switzerland & 1 & 1 & 1 & - & 1 & 1 & 1 & 6 \\
\hline Lithuania & 1 & 0 & 1 & - & 1 & 1 & 1 & 5 \\
\hline Finland & - & - & 1 & - & - & 1 & 1 & 3 \\
\hline France & 1 & 0 & 1 & 1 & 1 & 0 & 1 & 5 \\
\hline Canada & 1 & 1 & 1 & 1 & 1 & 1 & 1 & 7 \\
\hline Poland & 1 & 1 & 1 & 1 & 1 & 1 & 6 \\
\hline South Korea & 1 & 1 & - & 0 & 1 & 1 & 5 \\
\hline Mexico & 1 & & & & & & 6 \\
\hline & 1 & 1 & - & 1 & 1 & 1 & 1 \\
\hline
\end{tabular}


Table 2, cont.

\begin{tabular}{|l|l|l|l|l|l|l|l|l|}
\hline Norway & 1 & 1 & 1 & 1 & 1 & 1 & 1 & 7 \\
\hline Japan & 1 & 1 & 1 & - & 1 & - & 1 & 5 \\
\hline New Zealand & 1 & 1 & 1 & 1 & 1 & 1 & 1 & 7 \\
\hline Hungary & 1 & 1 & 1 & - & 1 & 1 & 1 & 6 \\
\hline Spain & 1 & 1 & 1 & 1 & 1 & - & 1 & 6 \\
\hline Germany & 1 & 1 & 1 & 1 & 1 & 1 & 1 & 7 \\
\hline United Kingdom & 1 & 1 & - & 1 & 1 & 1 & 1 & 6 \\
\hline Australia & 1 & 1 & 1 & 1 & 1 & 1 & 1 & 7 \\
\hline Austria & 1 & 1 & 1 & 1 & 1 & 1 & 1 & 7 \\
\hline Belgium & 1 & 1 & 1 & 1 & 1 & 1 & - & 6 \\
\hline Denmark & 1 & 1 & 1 & 1 & 1 & 1 & 1 & 7 \\
\hline Netherlands & 1 & 1 & 1 & 1 & 1 & 1 & 1 & 7 \\
\hline Sweden & 1 & 1 & 1 & - & 1 & 1 & 1 & 6 \\
\hline
\end{tabular}

Source: own study based on (OECD, 2020a, 2020b).

A total of 36 OECD countries were selected for the study which have a representative in the OECD Council. The median was 6 points. This constitutes $85.71 \%$ of the maximum number of points that could be obtained in the study. On average, the countries received 5.64 points in the survey. Figure 1 shows how the number of points scored by the countries is distributed (how many countries scored a given number of points).

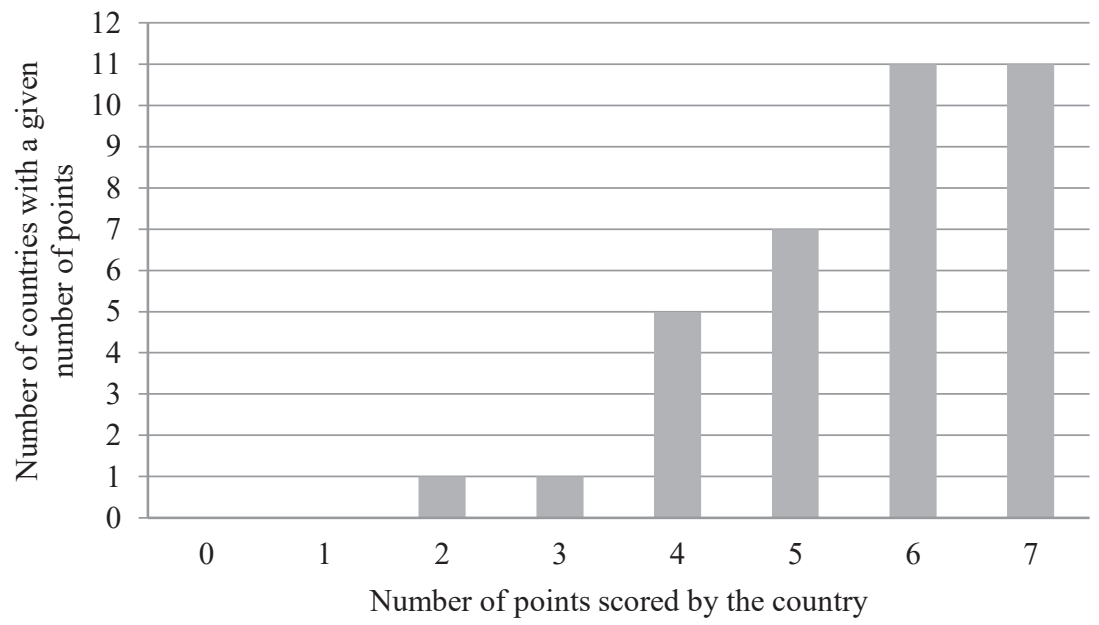

Fig. 1. Distribution of the number of points obtained by OECD countries

Source: own study based on Table 2 . 
It is worth noting that the average number of points scored by the member states is $80.57 \%$ of the total points. Such high compliance of national solutions with OECD good practices allows for concluding that solutions developed in the international space regarding transfer pricing, based on the example of good practices contained in the OECD Guidelines on advance pricing agreements and the procedures of mutual communication, are widely used.

Of the 36 countries surveyed, two of them - Chile and Finland - failed to receive half the points ( 3.5 points). None of the countries received 0 points, whereas 11 Member States scored a maximum of 7 points, i.e. Australia, Austria, Canada, Denmark, Estonia, Germany, Ireland, the Netherlands, New Zealand, Norway and the USA.

The most frequently introduced regulation in OECD member states is ensuring access to the mutual agreement procedure in matters regarding transfer pricing in national regulations -34 of the examined solutions contain provisions within this guideline. The second most frequently introduced practice relates to the publication of the information and documentation requirement that the state expects from the taxpayer in the scope of the request for mutual agreement procedure assistance. In their solutions, 32 countries out of the 36 surveyed included this good practice.

The results of the analysis indicate that countries are least willing to implement OECD Guidelines on the roll-back mechanism. Among those surveyed, fewer than half of them adopted provisions for this mechanism. One reason may be national tax arrangements, e.g. in the OECD report on the mutual agreement procedure and advance pricing agreement in Luxembourg, it was indicated that the theory allows for the use of the 'roll-back' mechanism, however the period of the advance pricing agreement may not exceed five years (OECD, 2019, p. 4).

The analysis shows that the regulations in force in Poland are to a large extent consistent with good practices contained in the OECD Guidelines. Poland received 6 out of the 7 assigned points. The area in which Poland did not gain any points concerned the prospects of submitting the possibility of using the roll-back mechanism was in the case of bilateral advance pricing agreements. Further work on transfer pricing regulations will potentially increase the clarity and transparency of regulations, which will result in the greater interest of companies in the use of instruments such as advance pricing agreements, and a more correct application of transfer pricing regulations.

\section{Conclusion}

Bringing together the tax solutions of national jurisdictions can lead to the elimination of significant tax differences which are one of the most important causes of the abuse of using transfer pricing, while at the same time increase the transparency of the rules for conducting related transactions and reduce the costs of preparing tax documentation. The OECD, thanks to the data obtained from both 
member states and non-associated countries, is able to develop guidelines further in line with the interests of all parties and through them impact further on global regulations. Another possible direction for the development of good practices is the emphasis on ethics and corporate social responsibility. As part of these activities, key stakeholders, including policy makers and business representatives, will develop broadly acceptable international moral standards of conduct.

The research conducted for this article confirms the thesis that OECD member states largely take into account good practices contained in the OECD Guidelines in the area of advance pricing agreements and the procedures of mutual communication in their legal solutions in the field of taxation. The study also indicated that in the analysed areas, Polish regulations mostly corresponded to OECD good practices.

The study presented in the article has its limitations. Firstly, only the OECD member states represented on the OECD council were covered by the analysis. A more complete picture of the influence of good practices could be obtained in further research by examining the strength of their impact on countries that complete and post their Dispute Resolution Profile on the OECD website, even though they are not OECD member countries.

Secondly, the study was largely based on data posted by countries on the OECD website. Not every country updates information every year, hence a problem with some countries that it is not possible to obtain more updated data. Finally, due to the multitude of good practices, it is not possible to include the analysis of all them within a single study.

\section{References}

Act of August 29, 1997, Tax code (Journal of Laws 2018 item 800).

Bańczyk, W. (2016). „Miękkie prawo, ale prawo”, czyli o obowiązku przestrzegania soft law. Internetowy Przeglad Prawniczy TBSP UJ, (1), 61-72.

Brychta, K., and Sulik-Górecka, A. (2019). Legal regulation for advance pricing agreements in the Czech Republic and Poland - a comparative case study. Acta Universitatis Agriculturae et Silviculturae Mendelianae Brunensis, 67(1), 209-224.

Burchart, R. (2015). Ceny transferowe a zarządzanie ryzykiem podatkowym w przedsiębiorstwach powiązanych. Prace Naukowe Uniwersytetu Ekonomicznego we Wroctawiu, (389), 41-49.

Bzymek-Iwanowicz, P. (2014). Ceny transferowe a system informacyjny rachunkowości. Zeszyty Naukowe Wydziału Nauk Ekonomicznych i Zarządzania Uniwersytetu Szczecińskiego. Finanse, Rynki Finansowe, Ubezpieczenia, 830(70), 27-36.

Chmiel, E. (2015). Objawy i konsekwencje manipulacji cenami transferowymi w aspekcie podatkowym: próba wstępnej diagnozy. Zeszyty Naukowe Studia i Prace Kolegium Zarządzania i Finansów, (142), 67-85.

Lanis, R., Richardson G., and Taylor G. (2019). Corporate moral ethics and transfer pricing aggressiveness in Australia. Australian Tax Forum, (34), 309-340.

Miller, A., and Oats, L. (2014). Principles of International Taxation. Haywards Heath: Bloomsbury Professional. 
Ministry of Finance. (2017). Transfer prices according to OECD and EU. Retrieved from https://www. finanse.mf.gov.pl/cit/ceny-transferowe1/ceny-transferowe-wg-oecd-i-ue

Ministry of Finance. (2018). Advance pricing agreements (APAs). Retrieved from https://www.podatki. gov.pl/ceny-transferowe/procedury-map-i-apa-statystyki/uprzednie-porozumienia-cenowe-apa/

OECD. (2002). Measuring the non observed economy: A handbook. Retrieved from https://www.oecd. org/sdd/na/1963116.pdf

OECD. (2016). BEPS action 14 on more effective dispute resolution mechanisms. Retrieved from http:// www.oecd.org/tax/beps/beps-action-14-on-more-effective-dispute-resolution-peer-review-documents.pdf

OECD. (2017). OECD Transfer Pricing Guidelines for Multinational Enterprises and Tax Administrations. Retrieved from https://read.oecd-ilibrary.org/

OECD. (2019). Luxembourg dispute resolution profile. Retrieved from https://www.oecd.org/ctp/dispute/Luxembourg-Dispute-Resolution-Profile.pdf

OECD (2020a). MAP Profiles. Retrieved from https://www.oecd.org/tax/dispute/country-map-profiles. $\mathrm{htm}$

OECD (2020b). Member countries. Retrieved from https://www.oecd.org/about/members-and-partners/

Przydatek, K. (2018). Ocena zmian w zakresie cen transferowych w Polsce i ich wpływ na obowiązki podatników. Finanse i Prawo Finansowe, 3(19), 55-65.

Rödl \& Partner. (2019). MAP, or how to avoid double taxation? Retrieved from http://www.roedl.net/pl/ pl/warto_wiedziec/ceny_transferowe/map_czyli_jak_uniknac_podwojnego_opodatkowania.html

Selezen, P., and Hrytsiuk I. (2019). Legal regulation of the procedure for advance pricing agreements in Ukraine. Juridical Tribune, 9(2), 480-491.

Sikka, P., and Willmott, H. Ch. (2010). The dark side of transfer pricing: Its role in tax avoidance and wealth retentiveness. Critical Perspectives on Accounting, 21(4), 342-356.

Sołtysik, M. (2015). Porozumienia cenowe jako instrument zwiększania pewności inwestowania w polskim prawie podatkowym. Zeszyty Naukowe Uniwersytetu Szczecińskiego. Ekonomiczne Problemy Ustug, (120), 105-117.

Taramountas, K. (2019). The mutual agreement procedure: Coordinating the global tax orchestra. LSE Law Review, (4), 39-62.

United Nations. (2017). Practical Manual on Transfer Pricing for Developing Countries. New York: United Nations.

Vega, A. (2012). International governance through soft law: The case of the OECD transfer pricing guidelines. Working Paper of the Max Planck Institute for Tax Law and Public Finance, (5), 3-34.

Wier, L. (2020). Tax-motivated transfer mispricing in South Africa: Direct evidence using transaction data. Journal of Public Economics, (184), 1-16.

Wiśniewski, P., and Komer, W. (2015). Ceny transferowe. Warszawa: Difin.

Zbaraszewska, A. (2017). Ceny transferowe w regulacjach prawa bilansowego i podatkowego. Zeszyty Naukowe Wydziatu Nauk Ekonomicznych i Zarządzania Uniwersytetu Szczecińskiego. Finanse, Rynki Finansowe, Ubezpieczenia, 4(88), 199-206.

\section{DOBRE PRAKTYKI W ZAKRESIE CEN TRANSFEROWYCH W WYBRANYCH PAŃSTWACH CZLONKOWSKICH OECD}

Streszczenie: W ciągu ostatnich dziesięcioleci obserwowany jest znaczny rozwój cen transferowych. Dostrzeżono, że ceny transferowe mają istotny wpływ na wiele obszarów zarządzania przedsiębiorstwem. Państwa, dostrzegając powagę zagadnienia oraz dbając o zabezpieczenie swojej bazy podatkowej, zaczęły przyjmować przepisy regulujące tę materię. Wychodząc naprzeciw zarówno przed- 
siębiorstwom, jak i regulatorom, międzynarodowe organizacje zajęły się opracowywaniem wskazań oraz ich promowaniem, tak aby przepisy dotyczące cen transferowych były jak najbardziej przejrzyste i transparentne. Jednymi z najszerzej rozpowszechnionych stały się dobre praktyki zawarte w „Wytycznych OECD”. Celem artykułu jest ocena rozwiązań wypracowanych w przestrzeni międzynarodowej dotyczących cen transferowych na przykładzie dobrych praktyk zawartych w „Wytycznych OECD” z zakresu uprzednich porozumień cenowych oraz procedury wzajemnego porozumiewania się. Analizą objęte zostały wszystkie państwa członkowskie OECD.

Słowa kluczowe: ceny transferowe, Wytyczne OECD, uprzednie porozumienia cenowe, procedura wzajemnego porozumiewania się. 